\title{
Bacterial adhesion on biomedical surfaces covered by yttria stabilized zirconia
}

\section{Perez-Tanoira, Ramon}

2016-01

Perez-Tanoira , R , Horwat, D , Kinnari , T J , Perez-Jorge , C , Gomez-Barrena , E , Migot , S \& Esteban , J 2016 , ' Bacterial adhesion on biomedical surfaces covered by yttria stabilized zirconia ' , Journal of Materials Science: Materials in Medicine , vol. 27 , no. 1 , 6 . https://doi.org/10.1007/s

http://hdl.handle.net/10138/223851

https://doi.org/10.1007/s10856-015-5625-x

publishedVersion

Downloaded from Helda, University of Helsinki institutional repository.

This is an electronic reprint of the original article.

This reprint may differ from the original in pagination and typographic detail.

Please cite the original version. 


\title{
Bacterial adhesion on biomedical surfaces covered by yttria stabilized zirconia
}

\author{
Ramón Pérez-Tanoira ${ }^{1,2}$ - David Horwat ${ }^{3}$ Teemu J. Kinnari ${ }^{2}$ • \\ Concepción Pérez-Jorge ${ }^{1} \cdot$ Enrique Gómez-Barrena $^{4}$. \\ Sylvie Migot $^{5} \cdot$ Jaime Esteban $^{1}$
}

Received: 6 August 2015/ Accepted: 9 November 2015/Published online: 26 November 2015

(C) Springer Science+Business Media New York 2015

\begin{abstract}
The aim of this study was to compare the bacterial adhesion of Staphylococcus spp. on Ti-6Al-4V with respect to Ti-6Al-V modified alloys with a set of Cubic yttria stabilized zirconia (YSZ) and Ag-YSZ nanocomposite films. Silver is well known to have a natural biocidal character and its presence in the surface predicted to enhance the antimicrobial properties of biomedical surfaces. Microbial adhesion tests were performed using collection strains and twelve clinical strains of Staphylococcus aureus and Staphylococcus epidermidis. The adherence study was performed using a previously published protocol by Kinnari et al. Both collection strains and clinical isolates have shown lower bacterial adhesion to materials modified with respect to the alloy $\mathrm{Ti}-6 \mathrm{Al}-4 \mathrm{~V}$ and the modification with silver reduced the bacterial adhesion for most of all the strains studied. Moreover the percentage of dead bacteria have been evaluated, demonstrating increased proportion of dead bacteria for the modified surfaces. Nanocrystalline silver dissolves releasing both $\mathrm{Ag}^{+}$and $\mathrm{Ag}^{0}$ whereas other silver sources release only
\end{abstract}

Ramón Pérez-Tanoira

ramontanoira@hotmail.com

1 Department of Clinical Microbiology, IIS-Fundación Jiménez Díaz, Ave Reyes Católicos 2, 28040 Madrid, Spain

2 Otorhinolaryngology-Head and Neck Surgery, University of Helsinki and Helsinki University Hospital, Helsinki, Finland

3 Institut Jean Lamour, UMR7198, Université de Lorraine, 54011 Nancy, France

4 Department of Traumatology and Orthopaedic, IIS-La Paz, 28046 Madrid, Spain

5 Centre de Compétences en Microscopies Electroniques et Microsondes (CC-MEM), Institut Jean Lamour, Parc de Saurupt, CS 50840, 54011 Nancy, France
$\mathrm{Ag}^{+}$. We can conclude that YSZ with nanocrystalline silver coating may lead to diminished postoperative infections and to increased corrosion and scratch resistance of YSZ incorporating alloys Ti-6Al-4V.

\section{Introduction}

Despite their importance in different aspects of modern medicine, the presence of an implanted device usually results in an increased susceptibility to infection for the patient $[1,2]$. Infection related to orthopaedic implants is an emerging problem occurring at a rate of $5 \%$ [3], and in many cases the only solution to an infected implanted device is its surgical removal [4]. The main pathogenic factor of prosthetic joint infections is the development of a bacterial biofilm. This structure allows bacteria to resist antimicrobial agents and immune responses [5], so patients with this type of infection require a longer period of antibiotic therapy and repeated surgical procedures [6, 7].

The prevention of bacterial adhesion without drugs may be one of the best ways to reduce these infections [5]. Hence, it is desirable to develop biomedical coatings for implants, which are repellent to bacteria, in order to minimize the colonization of the implant surface with circulating planktonic bacteria that can lead to biofilm development, especially against staphylococci, which are the leading cause of these infections [8].

Pure titanium and titanium alloys are frequently used as biomaterials in orthopaedic surgery because of their corrosion resistance, good biocompatibility, mechanical properties, and low cell toxicity [9]. Zirconia $\left(\mathrm{ZrO}_{2}\right)$ ceramics are also used in orthopaedic implant materials, offering superior corrosion, and scratch resistance relative to metal and better resistance to brittle fracture than 
alumina for example. Medical grade $\mathrm{ZrO}_{2}$ is usually stabilized with yttria, so it is somewhat stronger because of its nearly $100 \%$ tetragonal structure [10].

The main application of yttria stabilized Zirconia (YSZ) is in the manufacture of ball heads for total hip replacements. YSZ ceramics are used in structural and biomedical applications for the toughening effect on the material coupled with high bending strength, relatively low Young modulus, fairly high hardness and biocompatibility [11, 12].

Silver has been recognized as an effective antimicrobial agent that exhibits low toxicity in human and has diverse in vitro and in vivo application. Ag-nanoparticles have attracted considerable attention and have been used due to their antibacterial activity and the unlikeness to develop resistant microorganisms [5].

The reactive sputtering process is a valuable deposition tool that has proved its efficiency for the synthesis of oxide films incorporating silver nanoparticles [13] and YSZ incorporating noble metal nanoparticles [14].

The purpose of this study is to combine the higher corrosion resistance and scratch resistance of YSZ with a potential antimicrobial activity of silver for coating of $\mathrm{Ti}-$ $6 \mathrm{Al}-4 \mathrm{~V}$ alloys.

\section{Materials and methods}

\subsection{Materials synthesis and microstructure}

Cubic YSZ and Ag-YSZ nanocomposite films were deposited on Ti-6Al-V coupons by reactive magnetron cosputtering of $\mathrm{Ag}$ and $\mathrm{Zr} / \mathrm{Y}$ targets $(50 \mathrm{~mm}$ diameter, $3 \mathrm{~mm}$ thick and purity higher than $99.9 \%$ ). The current applied to the $\mathrm{Zr} / \mathrm{Y}$ target was kept constant at $0.7 \mathrm{~A}$. For deposition of the nanocomposite ceramic films, the same parameters were applied to the $\mathrm{Zr} / \mathrm{Y}$ target and the silver target was powered by an Advanced Energy MDX $1.5 \mathrm{~kW}$ DC using a current of $0.1 \mathrm{~A}$. The resulting silver content, characterized by the $\mathrm{Ag} /(\mathrm{Ag}+\mathrm{Zr}+\mathrm{Y})$ ratio of atomic concentrations, was close to 41 at $\%$ as measured by energy dispersive X-ray spectroscopy (EDSX). The deposition time was set such that the film thickness was close to 1 micron. After deposition, the samples were annealed in air at $300{ }^{\circ} \mathrm{C}$ for $2 \mathrm{~h}$. The film surface was observed using secondary electron detection with a Philips XL 30S-FEG scanning electron microscope (SEM) (Fig. 1). The surface morphology was characterized by the presence of facetted micronic crystals identified by EDS as silver particles as well as by rough features containing silver. In addition, $\mathrm{X}$-ray diffraction (XRD) analysis was performed on YSZ and nanocomposite films deposited on glass substrates and annealed under the same conditions (not shown here).

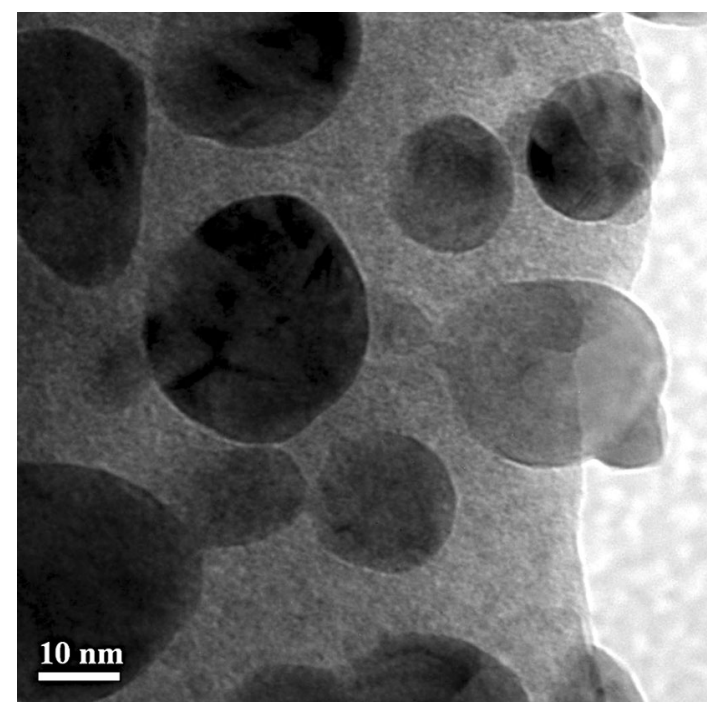

Fig. 1 shows the SEM image of the film surface of a Ag/YSZ nanocomposite layer deposited on a $\mathrm{Ti}-6 \mathrm{Al}-\mathrm{V}$ coupon after annealing in air at $300{ }^{\circ} \mathrm{C}$. The facetted crystals were identified to metallic silver using EDSX. TEM analysis was conducted on a cross section lamella, which evidenced the nanocomposite architecture of the film as consisting of silver nanoparticles in the 10-20 nm range embedded by the YSZ matrix

\subsection{Staphylococcal adhesion experiments}

Ti-6Al-4V coupons coated with Ag-YSZ were compared against controls of uncoated Ti-6Al-4V coupons and $\mathrm{Ti}-$ $6 \mathrm{Al}-4 \mathrm{~V}$ coupons coated with YSZ film.

Staphylococcal adhesion experiments were performed as described by Kinnari et al. [15]. Briefly, the biofilmforming collection strains S. aureus 15981 [15], Staphylococcus epidermidis ATCC 35984 and six clinical strain from each species, isolated from patients with implant-related infection by sonication [16], were cultured overnight in tryptic soy broth (bioMérieux, Marcy l'Etoile, France) at $+37{ }^{\circ} \mathrm{C}$ in $5 \% \mathrm{CO}_{2}$ atmosphere. After culturing, bacteria were harvested by $10-\mathrm{min}$ centrifugation at $3500 \times \mathrm{g}$ at room temperature. Supernatant was discarded and the pellet was washed three times with sterile phosphate buffered saline (PBS). Bacteria were then suspended and diluted in PBS to $10^{8}$ colony-forming units $(\mathrm{CFU}) / \mathrm{mL}$. The biomaterial discs were placed into the bacterial suspension and incubated for $90 \mathrm{~min}$ at $+37^{\circ} \mathrm{C}$. Afterwards, the biomaterial plates were rinsed three times with sterile PBS to remove any nonadherent bacteria [15].

Dried plates were stained for $15 \mathrm{~min}$ with a rapid fluorescence staining method using the Live/Dead ${ }^{\circledR}$ Backlight $^{\mathrm{TM}}$ Bacterial Viability Kit (Invitrogen, Eugene, OR, USA) [17]. On each plate, eight fields were viewed and photographed with Nikon Coolpix 8400 (Nikon, Melville, NY, USA) under a fluorescence microscope at $\times 40$ magnification (Fig. 2). All experiments were performed in 


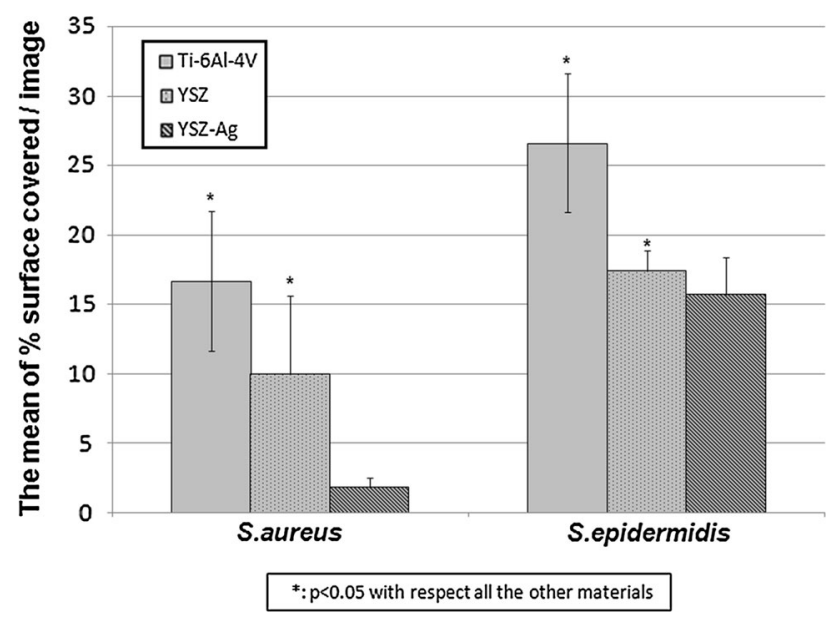

Fig. 2 Mean percentage of biomaterial surface covered with each collection strain of $S$. aureus and $S$. epidermidis for the respective material. The error bars represent the standard deviation

triplicates. The number of microphotographs studied was 24 per each material and bacterium. The surface area covered with adhered bacteria was calculated using the ImageJ software (National Institue of Health, Bethesda, MD, USA).

\subsection{Statistical analysis}

For the statistical study, non-parametric tests have been used. Mann-Whitney or Wilcoxon tests were used for two samples and the Kruskal-Wallis test was used for more than two samples. EPI-Info software version 3.5.1 (CDC, Atlanta, GA. USA) was used to perform the statistical studies.

\section{Results}

\subsection{Ag-YSZ thin film morphology}

XRD analysis evidenced the formation of face centered cubic metallic silver after annealing. Further analysis of the microstructure of the film cross section by transmission electron microscopy (TEM) proved that ceramic nanocomposite film was formed including silver nanoparticles of $15 \mathrm{~nm}$ of average size embedded by the oxide matrix (Fig. 1). Hence, silver nanoparticles are present within the film and silver micro particles grew on top of the film during annealing.

\subsection{Bacterial adhesion tests}

\subsubsection{Bacterial adhesion for collection strains}

The adherence results, represented in Fig. 2 indicates that both strains showed lowered bacterial adherence to modified surface materials compared to untreated Ti-6Al$4 \mathrm{~V}$ surface $(P \leq 0.0001$ for all the comparisons except $P=0.0002$ for $S$. aureus with respect to $\mathrm{Ti}-6 \mathrm{Al}-4 \mathrm{~V}$ with YSZ). Figure $3 a, b$ shows an example of the images obtained for $S$. aureus and S. epidermidis.

The incorporation of silver produced a decrease of bacterial adherence for both bacteria with respect to $\mathrm{Ti}-$ $6 \mathrm{Al}-4 \mathrm{~V}$ coated with YSZ $(P<0.0001$ for $S$. aureus and $P=0.0112$ for $S$. epidermidis). S. epidermidis showed more adhesion than $S$. aureus to all materials $(P<0.0001$ for all materials).

\subsubsection{Bacterial adhesion for clinical strains}

The adherence results, represented in Fig. 4a, b, indicates that all clinical strains showed low adherence to modified surface materials $(P<0.05)$ except for the $S$. epidermidis strain p33 where no differences between Ti-6Al-4V and Ti-6Al-4V coated with YSZ were observed $(P=0.6724)$.

Moreover, Ti-6Al-4V coated with Ag-YSZ showed significantly lower adhesion except with respect to YSZcoated coupons for $\mathrm{p} 2$.

Figure 5 shows that considering $\mathrm{Ti}-6 \mathrm{Al}-4 \mathrm{~V} S$. aureus strain p61 and $S$. epidermidis strain p6 showed the highest adherence and for the modified surface materials the highest adherence was shown by $S$. aureus $\mathrm{p} 4$ and $S$. epidermidis p33.

\subsection{Percentage of the dead bacteria on each surface}

\subsubsection{Percentage of the dead collection strain bacteria on each surface}

Only materials with YSZ or Ag-YSZ modified surface showed bactericidal effect on collection strain bacteria. YSZ-coated coupons for both collection strains (mean percentage of dead bacteria per image (\% dead bacteria) \pm standard deviation $(\mathrm{SD})=9.64 \pm 9.20$ for $S$. aureus and $7.23 \pm 7.08$ for S. epidermidis) and Ag-YSZ only for $S$. epidermidis $(22.12 \pm 21.89)(P=0.0014$ for $S$. epidermidis). There were not statistically significant difference between $S$. aureus and S. epidermidis for Ti-6Al4V with YSZ.

\subsubsection{Percentage of the dead clinical strain bacteria on each surface}

The incorporation of silver showed bactericidal effect for all the clinical strains of $S$. aureus with respect to Ti-6Al4V (Fig. 6a) except for p18 $(P=0.1878)$. However, considering the clinical strains of $S$. epidermidis there was statistically significant difference only for p53 $(P<0$. 0001). 

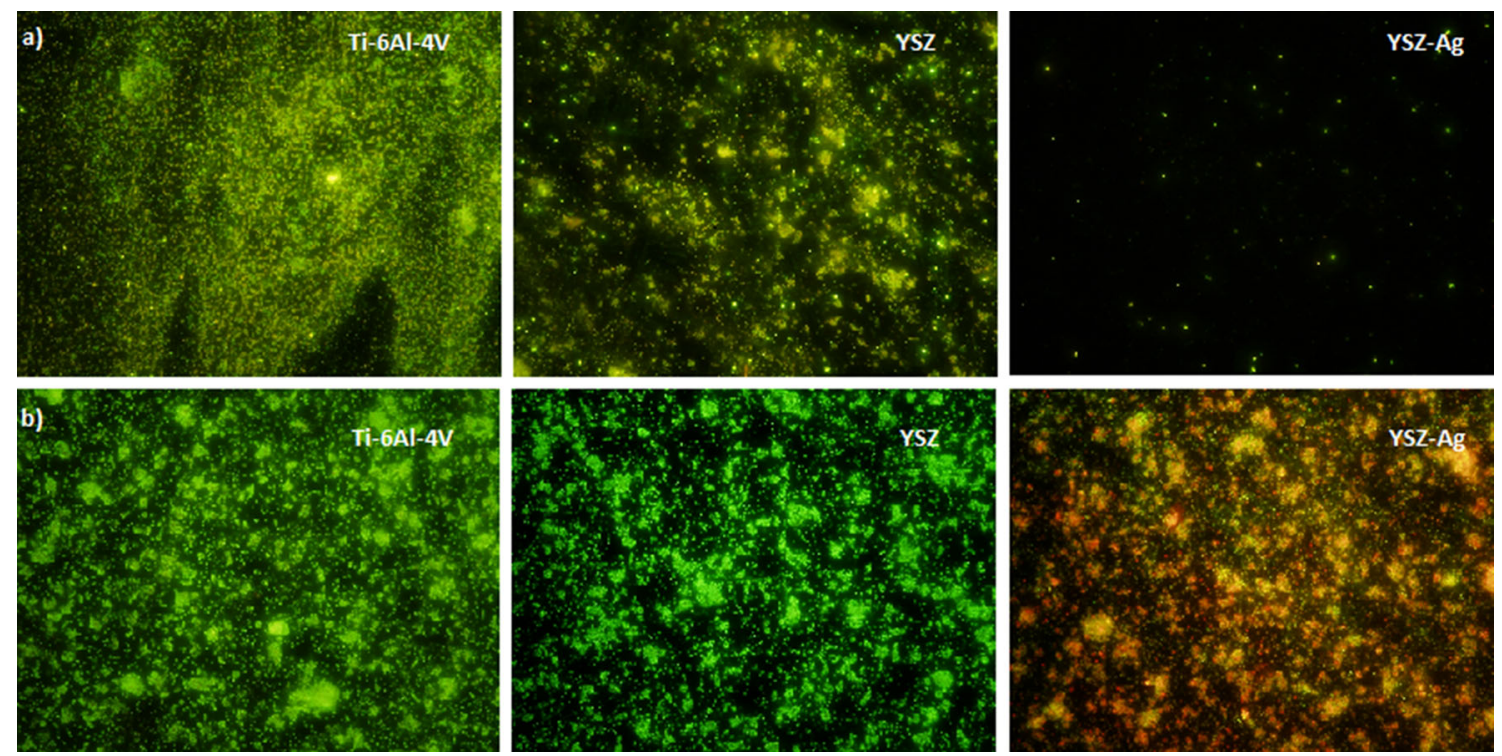

Fig. 3 Example of the fluorescence microscope images for Ti-6Al-4V surface, Ti-6Al-4V coated with YSZ surface and Ti-6Al-4V coated with YSZ-Ag surface covered by the collection strains of a $S$. aureus and $\mathbf{b} S$. epidermidis

Figure 7 shows that each clinical strain seemed to have variable behaviour depending on the implant material. However, in p2 and p95 strains the bactericidal effect was always weak and in 44 and p18 strong, whereas any of the materials killed p74 strain bacteria.

\section{Discussion}

Bacterial adhesion to a material surface is the first step in biofilm development $[15,18]$. It is determined by the combination of interactions between bacterial surface, the substrate surface and the environment around them. It depends largely on the structure and atomic composition of the surface of implanted biomaterials, surface charge, hydrophobicity, and its roughness and surface morphology [19].

Coated implants resistant to infection could prevent the progression and development of infections [20]. With increasing bacterial resistance against antibiotics, silver and its compounds-historically well known for their antimicrobial effect-have come back into the focus of research [21].

YSZ is among the most used ceramic materials in dental implants, due to its mechanical properties and biocompatibility, because YSZ implants are bio-inert and have excellent resistance to wear and corrosion. Due to the high flexural strength and fracture resistance [22, 23], YSZ could be an excellent alternative to Ti-6Al-4V alloys. With regards to osseointegration, the results are in fact comparable or even better than those obtained for titanium
[24]. Moreover, it does not induce cytotoxic effect on fibroblasts [23]. It is a ceramic based on zirconium oxide, in which the particular crystalline structure becomes stable at room temperature by the addition of yttrium oxide. Pure $\mathrm{ZrO}_{2}$ has a stable tetragonal crystal structure at temperatures above $1273 \mathrm{~K}$, but changes to a monoclinic crystal structure below that temperature and to cubic above $2643 \mathrm{~K}$

The objective of the study was to assess whether it is possible to combine the beneficial properties of YSZ with the antimicrobial properties of silver.

YSZ AND Ag-YSZ coated plates showed a decreased bacterial adherence of collection and clinical strains of $S$. aureus and S. epidermidis in comparison to uncoated plates supporting the results of the previous studies [22, 25]. Moreover, the incorporation of silver produced a decrease of the adhesion compared to YSZ only.

The mechanism of the antimicrobial effect shown by YSZ coating is not clear. However, as shown by Poortinga et al. [26] the electric conductivity of superficial structure of zirconium oxide could explain the reduction on the bacterial adherence compared with uncoated Ti-6Al-4V. During bacterial adhesion, depending on the specific resistivity of the substratum, bacteria either donate to or accept electrons from the substratum. It could be hypothesized that YSZ donates electrons to the bacteria which produces a repulsive force between the bacteria and the substratum and leads to a lowered bacterial adhesion.

The bactericidal mechanism of silver targets cysteine residues, which are omnipresent in proteins. Therefore, silver is effective on a large spectrum of bacteria, and 
Fig. 4 Mean percentage of biomaterial surface covered with each clinical strains of a $S$. aureus and $\mathbf{b} S$. epidermidis for each material. The error bars represent the standard deviation

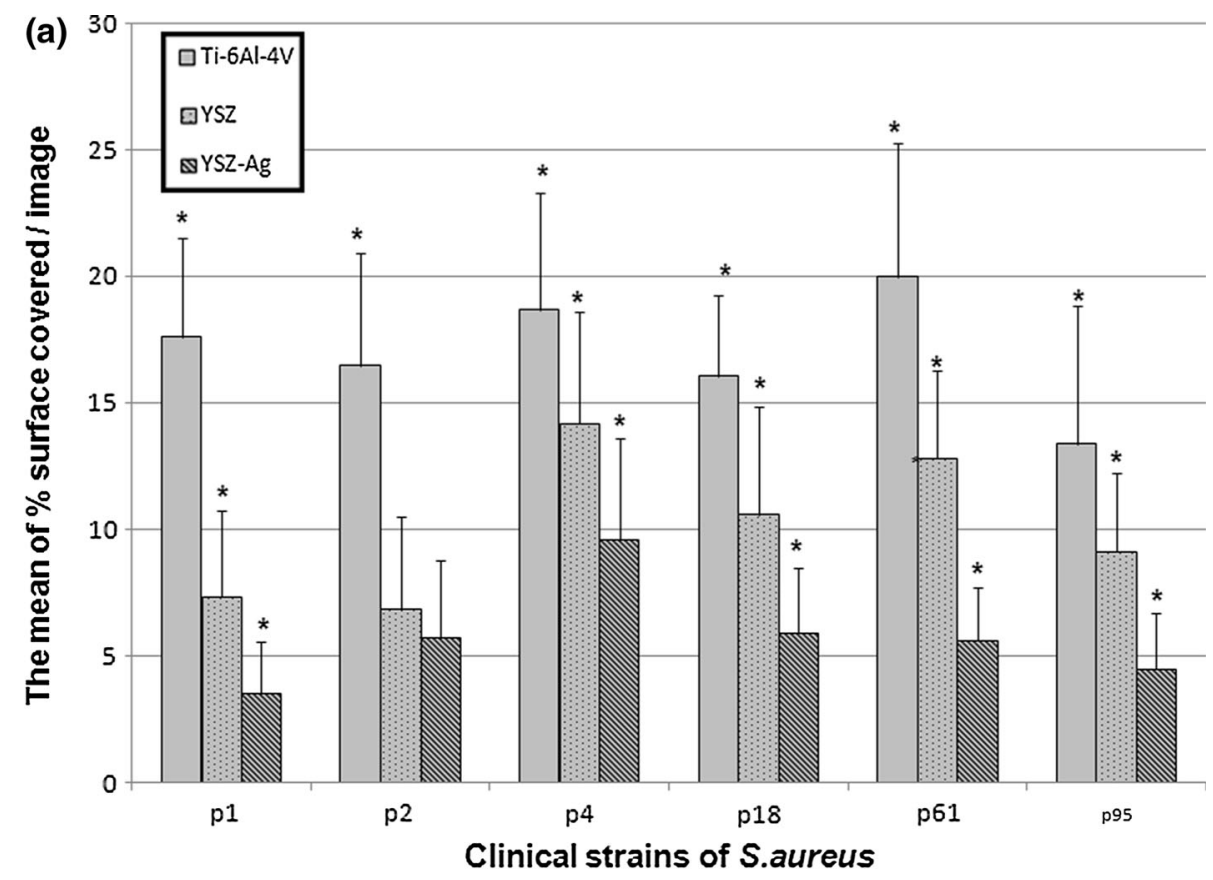

${ }^{*}: p<0.05$ with respect all the other materials

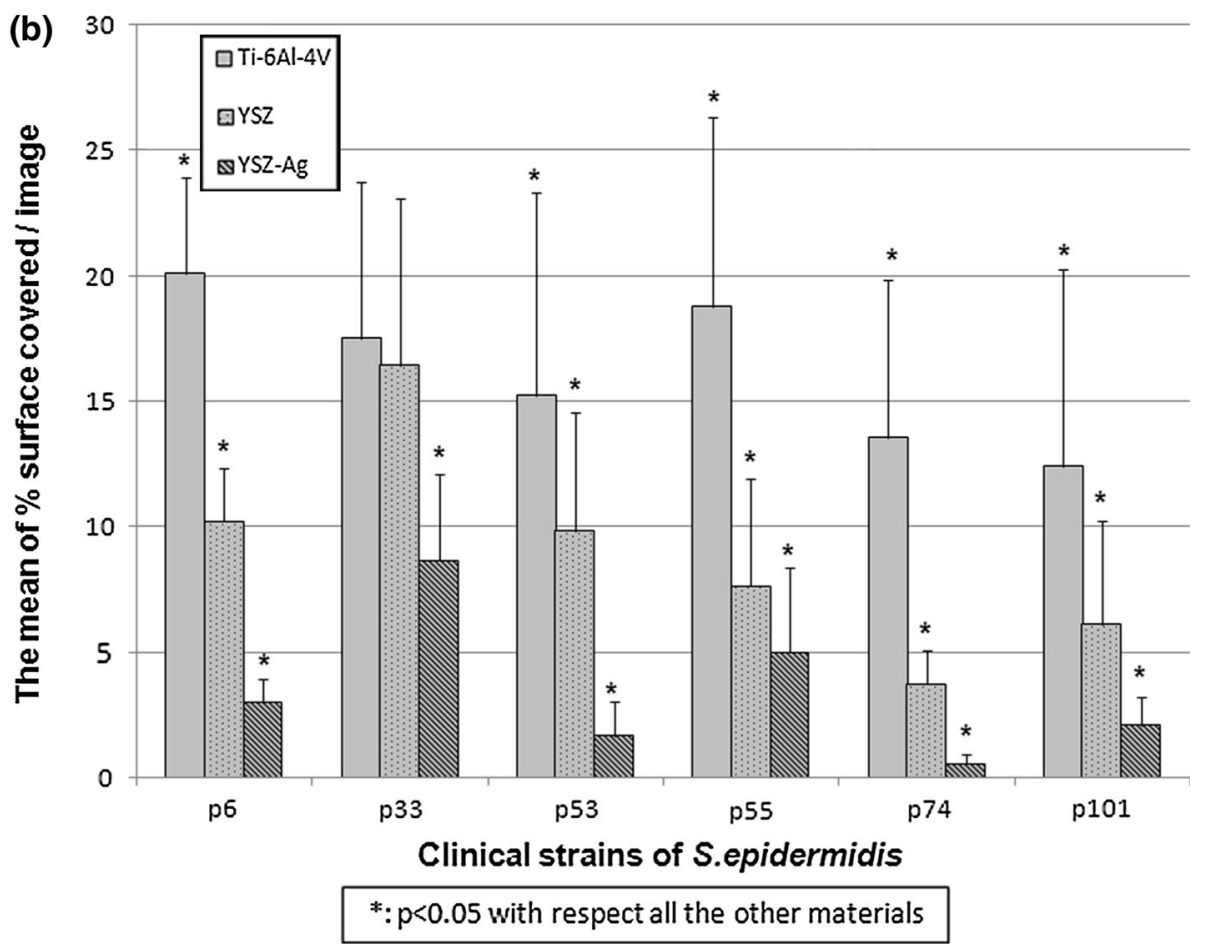

target based mutation to silver resistance is unlikely to develop. It could be for this reason that the silver coating has a similar bactericidal effect for most of the strains.

Nanocrystalline silver is a unique structure of silver; it is a metastable, high-energy form of silver prepared by reactive sputtering, producing crystals of oxidized silver and metallic silver. Bulk silver placed in water does not dissolve, but nanocrystalline silver dissolves to provide a concentration in solution of around $70 \mathrm{ppm}$ releasing both $\mathrm{Ag}^{+}$and $\mathrm{Ag}^{0}$ whereas other silver sources release only $\mathrm{Ag}^{+}$[27].

Furthermore, released silver ions act immediately, as shown by blockage of protein activities, which is beneficial for preventing local infections. Possibly the main 
Fig. 5 Comparison of the mean percentage of biomaterial surface covered with the different clinical strains of a $S$. aureus and $\mathbf{b} S$. epidermidis for each material. The error bars represent the standard deviation
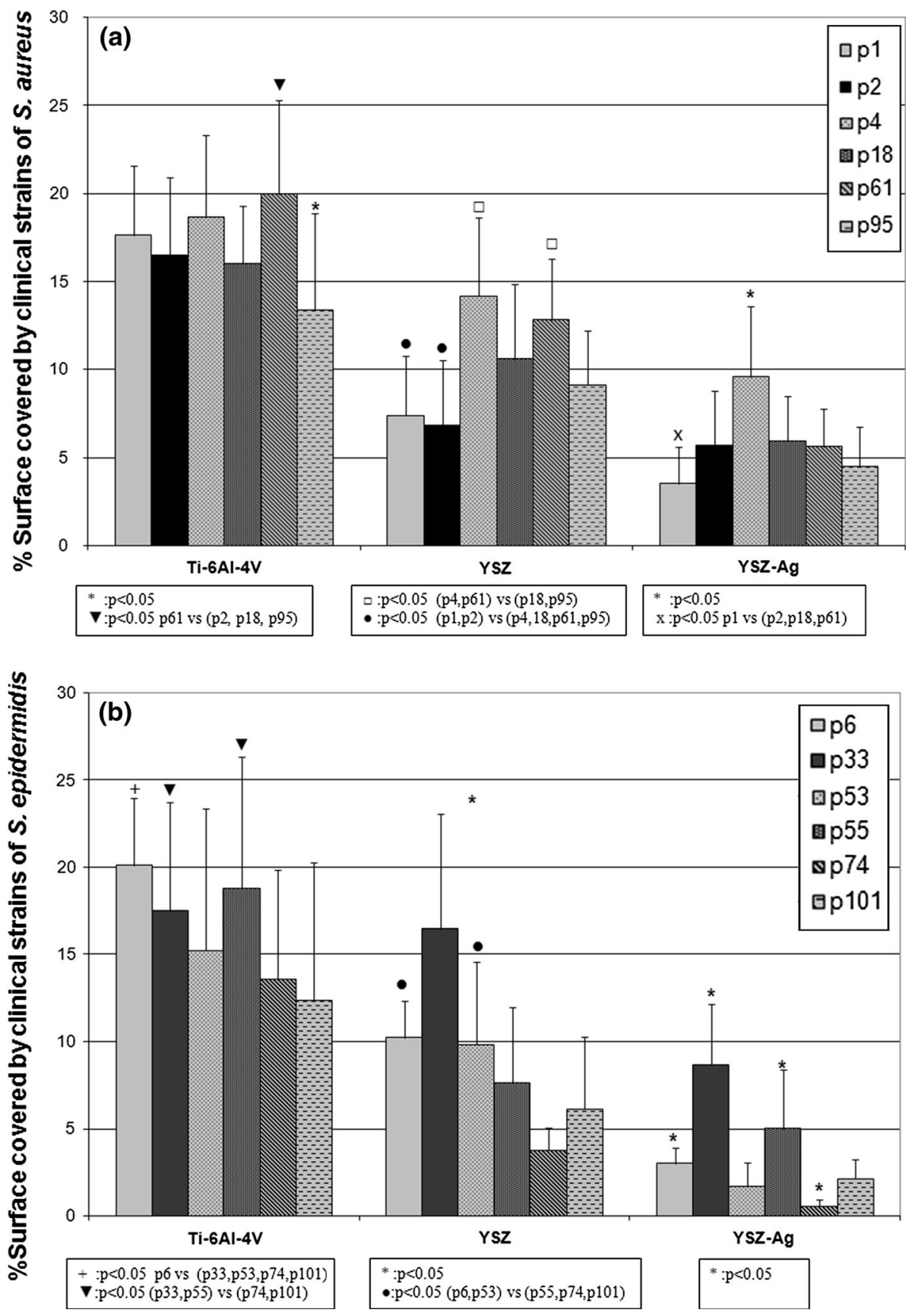

indication for these compounds will be prevention of perioperative infections [20].

Silver has been known to be eliminated via the renal system, and can be absorbed easily through the gastrointestinal system [28]. Hence, metallic silver appears to present a minimal risk to health. In contrast, soluble silver compounds are more readily absorbed than insoluble metallic silver and, therefore, have a greater potential to cause adverse effects in humans [29].

S. epidermidis showed higher adherence for all materials than $S$. aureus. In this study, we first evaluated the adherence of collection strains. These strains can have lower genetic load than clinical strains isolated from patients, because they are laboratory-adapted strains that lose genes due to several passages on culture medium. Further experiments were performed to evaluate adherence using clinical strains isolated from patients with a diagnosis of prosthetic joint infection which often show different properties compared to laboratory-adapted collection strains [30]. These experiments showed a variability in the response of the different strains probably due to the different pathogenic properties of the strains. For this reason 
Fig. 6 Mean percentage of dead bacterial of each clinical strains of a $S$. aureus and $\mathbf{b} S$. epidermidis for each material. The error bars represent the standard deviation
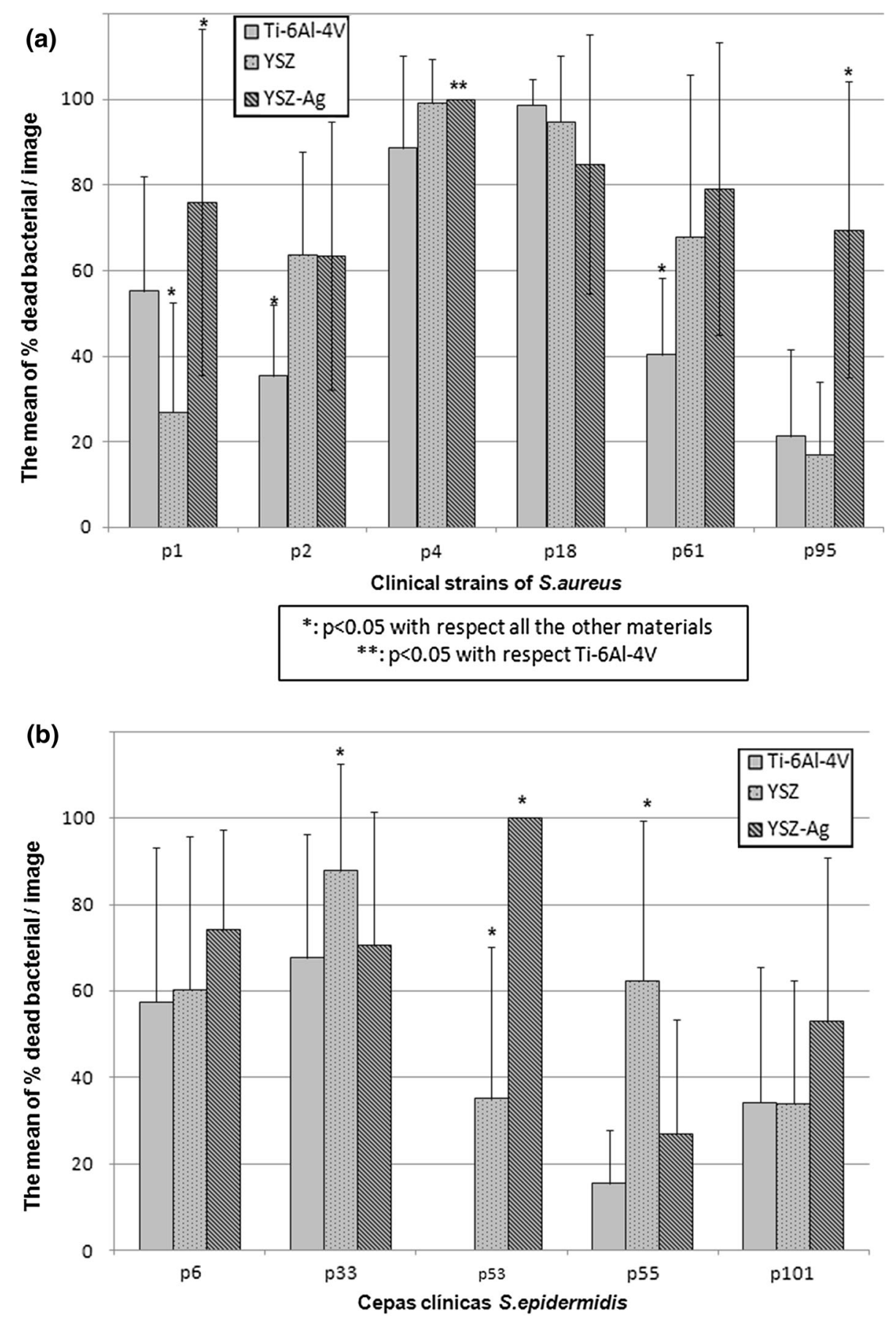

${ }^{*}: p<0.05$ with respect all the other materials

we think that, when studying bacterial adhesion, it is advisable to study the largest possible number of strains to predict reliably the effect of in vivo.

Finally, and given the fact that resources are increasingly scarce; the economy is a factor to be taken into account. It is true that silver-coated prostheses are 5-7\% more expensive than uncoated prostheses [31]. However, the significant decrease in the period of hospitalization and decreased revision surgeries should be factors to be taken into account when considering the cost-effectiveness of the changes to be implemented in the future relationship [32]. 
Fig. 7 Comparison of the mean percentage of dead bacterial for the different clinical strains of a $S$. aureus and b $S$. epidermidis for each material. The error bars represent the standard deviation
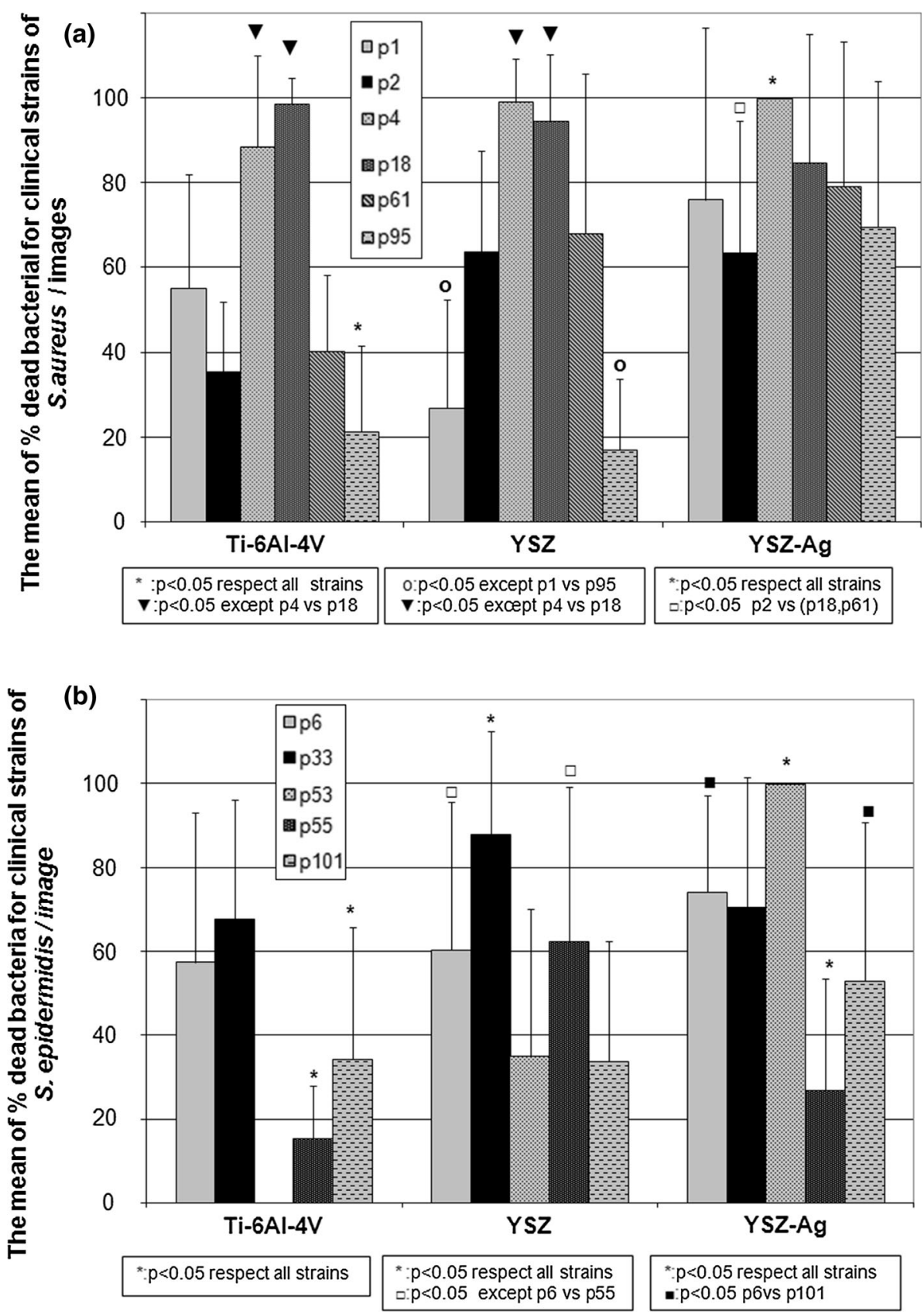

\section{Conclusions}

The combination of osteointegration properties of YSZ with the likely broad-spectrum antimicrobial activity and low risk of resistance development to silver nanoparticles makes Ag-YSZ nanocomposite film potential candidate for clinical applications. This is largely supported by this study using clinical bacterial strains obtained from infected patients. Future studies must analyze the effect of Ag-YSZ on biofilm development, which requires longer incubation times and provides more silver elution that can have a prolonged effect on sessile cells. This effect cannot be detected in adhesion experiments, where only immediate interactions between bacteria and the surface can be studied.

Acknowledgments This study was realized thanks to a help of the Program CONSOLIDER-INGENIO 2010 FUNCOAT-CSD200800023 and by a Grant from the Spanish MINECO (MAT2013-48224C2-2-R). 


\section{Appendix}

Certain figures in this article are difficult to interpret in black and white. The full colour images can be found in the online version.

\section{References}

1. Andriole VT, Nagel DA, Southwick WO. A paradigm for human chronic osteomyelitis. J Bone Jt Surg Am. 1973;55(7):1511-5.

2. Rochford ET, Richards RG, Moriarty TF. Influence of material on the development of device-associated infections. Clin Microbiol Infect. 2012;18(12):1162-7.

3. Guggenbichler JP, Assadian O, Boeswald M, Kramer A. Incidence and clinical implication of nosocomial infections associated with implantable biomaterials-catheters, ventilatorassociated pneumonia, urinary tract infections. GMS Krankenhhyg Interdiszip. 2011;6(1):Doc18.

4. Katsikogianni M, Missirlis YF. Concise review of mechanisms of bacterial adhesion to biomaterials and of techniques used in estimating bacteria-material interactions. Eur Cell Mater. 2004; 8:37-57.

5. Perez-Tanoira R, Perez-Jorge C, Endrino JL, Gomez-Barrena E, Horwat D, Pierson JF, et al. Bacterial adhesion on biomedical surfaces covered by micrometric silver Islands. J Biomed Mater Res A. 2012;100(6):1521-8.

6. Perez-Tanoira R, Isea-Pena MC, Celdran A, Garcia-Vasquez C, Esteban J. Bacterial adherence to different meshes used in abdominal surgery. Surg Infect (Larchmt). 2014;15(2):90-3.

7. Prieto-Perez L, Perez-Tanoira R, Petkova-Saiz E, Perez-Jorge C, Lopez-Rodriguez C, Alvarez-Alvarez B, et al. Osteomyelitis: a descriptive study. Clin Orthop Surg. 2014;6(1):20-5.

8. Perez-Jorge C, Conde A, Arenas MA, Perez-Tanoira R, Matykina E, de Damborenea JJ, et al. In vitro assessment of Staphylococcus epidermidis and Staphylococcus aureus adhesion on $\mathrm{TiO}(2)$ nanotubes on Ti-6Al-4V alloy. J Biomed Mater Res A. 2012;100(7):1696-705.

9. Adachi K, Tsurumoto T, Yonekura A, Nishimura S, Kajiyama S, Hirakata Y, et al. New quantitative image analysis of staphylococcal biofilms on the surfaces of nontranslucent metallic biomaterials. J Orthop Sci. 2007;12(2):178-84.

10. Roy ME, Whiteside LA, Katerberg BJ, Steiger JA. Phase transformation, roughness, and microhardness of artificially aged yttria- and magnesia-stabilized zirconia femoral heads. J Biomed Mater Res A. 2007;83(4):1096-102.

11. Piconi C, Burger W, Richter HG, Cittadini A, Maccauro G, Covacci V, et al. Y-TZP ceramics for artificial joint replacements. Biomaterials. 1998;19(16):1489-94.

12. Ichikawa $Y$, Akagawa $Y$, Nikai H, Tsuru H. Tissue compatibility and stability of a new zirconia ceramic in vivo. J Prosthet Dent. 1992;68(2):322-6.

13. Pierson JF. DH. Influence of the current applied to the silver target on the structure and the properties of $\mathrm{Ag}-\mathrm{Cu}-\mathrm{O}$ films deposited by reactive cosputtering. Appl Surf Sci. 2007; 253(18):7522-6.

14. Gries T, Catrin R, Migot S, Soldera F, Endrino JL, LandaCanovas AR, et al. Local modification of the microstructure and electrical properties of multifunctional Au-YSZ nanocomposite thin films by laser interference patterning. ACS Appl Mater Interfaces. 2014;6(16):13707-15.

15. Kinnari TJ, Soininen A, Esteban J, Zamora N, Alakoski E, Kouri VP, et al. Adhesion of staphylococcal and Caco-2 cells on diamond-like carbon polymer hybrid coating. J Biomed Mater Res A. 2008;86(3):760-8.

16. Esteban J, Gomez-Barrena E, Cordero J, Martin-de-Hijas NZ, Kinnari TJ, Fernandez-Roblas R. Evaluation of quantitative analysis of cultures from sonicated retrieved orthopedic implants in diagnosis of orthopedic infection. J Clin Microbiol. 2008; 46(2):488-92.

17. Boulos L, Prevost M, Barbeau B, Coallier J, Desjardins R. LIVE/ DEAD BacLight: application of a new rapid staining method for direct enumeration of viable and total bacteria in drinking water. J Microbiol Methods. 1999;37(1):77-86.

18. Del Pozo JL, Rouse MS, Euba G, Kang CI, Mandrekar JN, Steckelberg JM, et al. The electricidal effect is active in an experimental model of Staphylococcus epidermidis chronic foreign body osteomyelitis. Antimicrob Agents Chemother. 2009;53(10):4064-8.

19. Kinnari TJ, Esteban J, Martin-de-Hijas NZ, Sanchez-Munoz O, Sanchez-Salcedo S, Colilla M, et al. Influence of surface porosity and $\mathrm{pH}$ on bacterial adherence to hydroxyapatite and biphasic calcium phosphate bioceramics. J Med Microbiol. 2009;58(Pt 1): $132-7$.

20. Gordon O, Vig Slenters T, Brunetto PS, Villaruz AE, Sturdevant DE, Otto M, et al. Silver coordination polymers for prevention of implant infection: thiol interaction, impact on respiratory chain enzymes, and hydroxyl radical induction. Antimicrob Agents Chemother. 2010;54(10):4208-18.

21. Davenport K, Keeley FX. Evidence for the use of silver-alloycoated urethral catheters. J Hosp Infect. 2005;60(4):298-303.

22. Scarano A, Piattelli M, Caputi S, Favero GA, Piattelli A. Bacterial adhesion on commercially pure titanium and zirconium oxide disks: an in vivo human study. J Periodontol. 2004;75(2):292-6.

23. Piconi C, Maccauro G. Zirconia as a ceramic biomaterial. Biomaterials. 1999;20(1):1-25.

24. Lima EM, Koo H, Vacca Smith AM, Rosalen PL, Del Bel Cury AA. Adsorption of salivary and serum proteins, and bacterial adherence on titanium and zirconia ceramic surfaces. Clin Oral Implant Res. 2008;19(8):780-5.

25. Rimondini L, Cerroni L, Carrassi A, Torricelli P. Bacterial colonization of zirconia ceramic surfaces: an in vitro and in vivo study. Int J Oral Maxillofac Implant. 2002;17(6):793-8.

26. Poortinga AT, Bos R, Busscher HJ. Charge transfer during staphylococcal adhesion to TiNOX coatings with different specific resistivity. Biophys Chem. 2001;91(3):273-9.

27. Atiyeh BS, Costagliola M, Hayek SN, Dibo SA. Effect of silver on burn wound infection control and healing: review of the literature. Burns. 2007;33(2):139-48.

28. Secinti KD, Ozalp H, Attar A, Sargon MF. Nanoparticle silver ion coatings inhibit biofilm formation on titanium implants. J Clin Neurosci. 2011;18(3):391-5.

29. Drake PL, Hazelwood KJ. Exposure-related health effects of silver and silver compounds: a review. Ann Occup Hyg. 2005;49(7):575-85.

30. Perez-Tanoira R, Garcia-Pedrazuela M, Hyyrynen T, Soininen A, Aarnisalo A, Nieminen MT, et al. Effect of S53P4 bone substitute on staphylococcal adhesion and biofilm formation on other implant materials in normal and hypoxic conditions. J Mater Sci Mater Med. 2015;26(9):239.

31. Gosheger G, Hardes J, Ahrens H, Streitburger A, Buerger H, Erren M, et al. Silver-coated megaendoprostheses in a rabbit model-an analysis of the infection rate and toxicological side effects. Biomaterials. 2004;25(24):5547-56.

32. Hussmann B, Johann I, Kauther MD, Landgraeber S, Jager M, Lendemans S. Measurement of the silver ion concentration in wound fluids after implantation of silver-coated megaprostheses: correlation with the clinical outcome. Biomed Res Int. 2013;2013:763096. 